\title{
Rewriting Gregory the Great: the Prison Analogy in Napier Homily I
}

\begin{abstract}
The Old English homily known as Napier I survives in two distinct versions. At the heart of each version is a reworking of the opening chapter of Book IV of the Dialogi of Gregory the Great, the focus of which is an analogy comparing the epistemological limits facing humanity to the situation of a youth born in prison. Scholarly attention has focused primarily upon the different continuations of the two versions of Napier I and their connections to Archbishop Wulfstan II of York. This paper, however, is primarily concerned with the reworking of the Dialogi in the early part of the homily. My analysis shows how the Anglo-Saxon homilist consistently reworks Gregory’s Latin in ways that reflect the different concerns of the two writers. Where Gregory was concerned with providing reasoned, intellectual arguments to support belief in the mysteries of the faith, the author of the common core of Napier I adapts the Latin text for preaching purposes. As such, the text of Napier homily I both witnesses the importance of the Dialogi as a source in Anglo-Saxon England and provides an insight into the freedom with which such authoritative Latin sources could be adapted and reshaped by vernacular homilists.
\end{abstract}

The popularity of Gregory the Great's Dialogi in Anglo-Saxon England has been wellestablished. Nine complete or fragmentary manuscript copies of the Latin text survive from Anglo-Saxon England, in addition to three manuscripts in Anglo-Saxon script copied on the continent before the ninth century which might reasonably be associated with Anglo-Saxon missionary activity in Germany. ${ }^{1}$ From this evidence, as well as the evidence of surviving book lists, Michael Lapidge concludes that the Dialogi formed part of the 'small core of staple patristic texts' that would typically have been found in the libraries of Anglo-Saxon England. ${ }^{2}$ It is hardly surprising, then, that the text should have had a significant influence upon the production of literature throughout the Anglo-Saxon period. So much is apparent from the use of the Dialogi as a source by major Latin writers such as Aldhelm and Bede, but Gregory’s text was evidently also an inspiration for a range of vernacular authors, exerting an 
influence that extends to, but is not limited by, the production of the surviving Old English translation of the text known as the Old English Dialogues. ${ }^{3}$

One text in which the influence of the Dialogi can be found is the Old English homily known as Napier I. ${ }^{4}$ This text survives in three manuscript copies. In each copy, the bulk of the homily consists of a vernacular reworking of the opening chapter of Book IV of the Dialogi, which describes the spiritual blindness that afflicts post-lapsarian humanity and likens the plight of those born into a fallen world to that of a youth born within a dark prison, unable to give credence to that which he hears about the outside world but which he cannot verify for himself (Dialogi IV. I. 1-3). ${ }^{5}$ Following this common core, two copies of the homily-Cambridge, Corpus Christi College, 201, pp. 8-9 (MS C) and London, British Library, Cotton Tiberius A. xiii, ff. $115^{\mathrm{r}}-116^{\mathrm{v}}$ (MS L) — witness a continuation that draws on material from Book IV chapter VI of the Dialogi to describe the miracles of the saints and the joys of heaven. ${ }^{6}$ The third copy, uniquely preserved on ff. $1^{\mathrm{r}}-3^{\mathrm{r}}$ of Oxford, Bodleian Library, Hatton 113 (MS E), witnesses a shorter text, in which the Gregorian core of the homily is followed by a briefer and more generic conclusion. ${ }^{7}$

Both the longer and the shorter conclusions of the homily, though not the common Gregorian core, have been linked to Archbishop Wulfstan II of York. ${ }^{8}$ As a result, scholarly interest in Napier I has largely focused upon the extent of the archbishop’s involvement in the production of the two versions of the homily and their place within the canon of Wulfstan's work. The opening section of Napier I has consequently received relatively little critical attention. ${ }^{9}$ Although its connection to Dialogi IV. I. 1-3 has been known for more than a century, the precise dynamic of the relationship between the Latin text and the vernacular reworking has not been very closely examined. ${ }^{10}$ In particular, the treatment of Gregory’s analogy of the prison has been commented upon only in passing by scholars discussing this 
homily, and the extent and significance of the changes made in the vernacular text have not yet been fully acknowledged.

It is the purpose of this article, then, both to acknowledge, and to attempt to explain these changes. In what follows, I begin by outlining the context and significance of the prison analogy in the Dialogi in relation to Gregory's wider intellectual concerns. I shall then proceed with an examination of the makeup of the various copies and versions of Napier homily I, before conducting an analysis of the differences between the vernacular reworking of Dialogi IV. I. 1-3 and Gregory’s original Latin text. These differences can be readily explained as part of a deliberate reworking of Gregory's text in order to better fit the needs of an Anglo-Saxon preacher. I suggest that Napier homily I provides a valuable insight into the freedom with which anonymous Anglo-Saxon authors at times adapted and reshaped their authoritative Latin sources.

\section{Epistemology and the Prison Analogy in Dialogi Book IV}

The final book of the Dialogi displays a preoccupation with death, the afterlife, and the nature of the human soul. Departing from the style of Books I-III, Book IV begins by foregrounding theological enquiry in place of the miraculous and fantastic narratives so characteristic of the Dialogi as a whole. Opening with an account of the fall of humanity, the book addresses the limits of experiential knowledge and the difficulty of believing in spiritual mysteries that cannot be directly experienced. According to Gregory, Adam's guilt resulted not only in his expulsion from Paradise, but also in his loss of an enlightened mental state associated with direct experience of the heavenly life: 
Postquam de paradisi gaudiis, culpa exigente, pulsus est primus humani generis parens, in huius exilii atque caecitatis quam patimur aerumnam uenit, quia peccando extra semetipsum fusus iam illa caelestis patriae gaudia, quae prius contemplabatur, uidere non potuit. In paradiso quippe homo adsueuerat uerbis Dei perfrui, beatorum angelorum spiritibus cordis munditia et celsitudine uisionis interesse. Sed postquam huc cecidit, ab illo quo implebatur mentis lumine recessit. (IV. I. 1)

(After the first parent of the human race was expelled from the joys of paradise, driven by sin, he entered into the hardship of this exile and blindness which we suffer, so that, having reached beyond himself by sinning, he could no longer see those joys of the heavenly homeland, which he previously contemplated. Certainly, in paradise this man had been accustomed to enjoy the words of God and to be amongst the spirits of the blessed angels in purity of heart and loftiness of vision. But after he fell hither, he withdrew from the light of the mind with which he used to be filled.)

Gregory goes on to discuss the consequences of this experiential fall for the human race as a whole: whereas Adam, in his subsequent exile, was able to recall his previous vision of the joys of Paradise, his descendants are reliant upon his testimony. In such a situation, Gregory points out, people are inclined to doubt that which they cannot experience for themselves. It is to demonstrate this tendency towards scepticism that Gregory employs his prison analogy:

Ac si enim praegnans mulier mittatur in carcerem ibique puerum pariat, qui natus puer in carcere nutriatur et crescat; cui si fortasse mater, quae hunc genuit, solem, lunam, stellas, montes et campos, uolantes aues, currentes equos nominet, ille uero qui est in carcere natus et nutritus nihil aliud quam tenebras carceris sciat, et haec quidem esse audiat, sed quia ea per experimentum 
non nouit, ueraciter esse diffidat; ita in hac exilii sui caecitate nati homines, dum esse summa et inuisibilia audiunt, diffident an uera sint, quia sola haec infima, in quibus nati sunt, uisibilia nouerunt. (IV. I. 3)

(It is as if a pregnant woman is thrown into prison where she gives birth to a boy, who, having been born, is nurtured and grows in the prison. Suppose his mother, who gave birth to him, describes for him the sun, the moon, the stars, the mountains and the fields, the flying birds, the running horses - truly, he who is born and nurtured in the prison knows nothing more than the darkness of the prison. He may indeed hear that these things exist, but because he had not known them by experience, he is doubtful of the truth. So it is for men born into the darkness of this exile, while they hear that lofty and invisible things exist, they will doubt whether they are true, because they have known only the lowest, visible things into which they are born.)

Gregory's use here of the prison as an analogy for the limitations of the human experience stands within a long tradition of classical and patristic thought. In its concern with matters of epistemology, it recalls, of course, the famous ‘allegory of the cave’ recounted in Plato’s Republic, and it is possible that Gregory's rather different analogy forms part of the afterlife of Plato's influential parable. ${ }^{11}$ However, the prison, with its rich background of biblical and liturgical imagery, was a fertile source for analogy and metaphor in early Christian writing generally, and Gregory was himself no stranger to the realities of incarceration and confinement in the late Antique world. ${ }^{12}$ It need not be assumed, therefore, that Gregory’s analogy has its origins in the 'allegory of the cave'.

Indeed, Gregory’s development of the prison analogy indicates that he is not, in fact, primarily concerned with emphasizing the epistemological limits of humanity’s material existence, but with showing how, by means of grace, these limits can be transcended. For 
Gregory, the situation of the faithful is in reality unlike that of the boy born in prison, and his intention throughout Book IV is to show that certainty regarding the mysteries of the faithspecifically the fate of the soul after death—is made possible for Christians within the world through the coming of Christ:

Vnde factum est, ut ipse inuisibilium et uisibilium creator ad humani generis redemptionem Vnigenitus Patris ueniret, et sanctum Spiritum ad corda nostra mitteret, quatenus per eum uiuificati crederemus, quae adhuc scire experimento non possumus. Quotquot ergo hunc Spiritum, hereditatis nostrae pignus, accepimus, de uita inuisibilium non dubitamus. (IV. I. 4)

(Whence it came to pass that the only begotten of the Father, the creator of things visible and invisible, came unto the redemption of the human race, and that he might send the Holy Spirit into our hearts. Thus we are enlivened by him to believe that which as yet we cannot know through experience. Therefore, as many of us as have received this Spirit, a pledge of our inheritance, we do not doubt the life of invisible things.)

Those who have not themselves received this revelatory gift of the Holy Spirit should place their trust in the testimony of those who have. Only a foolish boy, Gregory concludes, would doubt his mother's testimony simply because he cannot see the things that she described (IV. I. 5).

As Matthew Dal Santo has recently demonstrated, Gregory’s concern with the limits of human epistemology in Dialogi Book IV must be seen as part of his defence of the cult of the saints which the previous three books celebrate. ${ }^{13}$ Intrinsic to the appeal of the cult of the saints in the late sixth century (and beyond) was the assumption of their miraculous and intercessory powers after death. This assumption was threatened, however, by 'arguments of a 
rationalist, materialist, and empiricist kind', questioning the basis of Church teaching about the fate of the soul after death, which 'were being put forward, apparently in Gregory’s circle at Rome, in 593-4'. ${ }^{14}$ The analogy of the prison forms part of Gregory’s response to such arguments, as Gregory seeks to undermine the 'materialist-empiricist' challenge voiced by his interlocutor Peter the Deacon, claiming a rational and experiential basis for belief in invisible mysteries. ${ }^{15}$ Central to Gregory's argument is what he sees as the empirical fact of Christ's Incarnation. Christ’s appearance on earth in human form provides direct, experiential evidence for the truth of the spiritual mysteries; through the subsequent gift of the Holy Spirit, he also makes available a spiritual knowledge which is, for Gregory, equivalent to such direct experience.

The progression of Gregory's argument can be seen in the presentation of the prison analogy itself. At first glance, there is something unsatisfactory about the development of this analogy, which starts from the position that the youth's doubts arise naturally from the situation in which he finds himself and ends by chastising him for not believing his mother's testimony. However, this seeming volte-face in fact results from a shift in the terms of the analogy during the course of Gregory's teaching. As the analogy is first introduced, the mother's account of the world outside the prison represents Adam's unverifiable testimony concerning his prior experience of the spiritual mysteries. In such a situation, doubt is inevitable, and it was for this reason (Vnde factum est) that Christ came to dispel such doubts. As the analogy concludes, therefore, the mother's account now stands in place of the testimony of those inspired by the Holy Spirit to spiritual experience of the invisible mysteries (eisque iam per Spiritum sanctum inuisibilium experimentum habentibus, IV. I. 5), whose testimony is vouchsafed by the evidence of Christ's incarnation.

\section{The Composition of Napier Homily I}


Before considering in detail the treatment of Gregory's Dialogi in Napier homily I, it is necessary to examine further the nature and composition of the Old English text and its likely relationship to its ultimate Latin source. As has been said above, Napier I is a composite text surviving in three manuscript copies which preserve two distinct versions. Both versions consist of the same original core comprising the vernacular reworking of Dialogi IV. I. 1-3, to which two separate continuations have been added. Both of these continuations are explicitly homiletic, and both can be connected, in different ways, to Archbishop Wulfstan. The longer continuation of the homily—which concludes with a sentence that also occurs near the beginning of Wulfstan's Sermo ad populum — has been linked to Wulfstan on the grounds that it exhibits the archbishop's own characteristic prose style and idiom. ${ }^{16}$ The further use of Dialogi Book IV as a source in this concluding passage strongly suggests that it was conceived specifically as a direct continuation of the earlier Gregorian material in Napier I. The shorter version of the homily also declares the influence of Wulfstan. Following the Gregorian core, this version of the homily concludes with an exhortation to contemplate Christ's sacrifices for mankind and to think upon judgement day which seems to have been redacted from a range of other homilies associated with Wulfstan. ${ }^{17}$

The manuscript evidence of the three surviving copies of Napier I similarly supports a connection with the orbit of Archbishop Wulfstan. The earliest of the three manuscript witnesses is probably MS L, a Worcester product of the early-eleventh century. ${ }^{18}$ In addition to the longer text of the homily, the manuscript also contains the so-called Liber Wigorniensis, an early-eleventh century cartulary relating to the diocesan estates, which may very well have been produced under Wulfstan's own supervision, probably in the early years of his episcopate following his promotion to the see of Worcester (with York) in $1002 .{ }^{19}$ The text of both the cartulary and the homily that follows it shows additions and corrections in a 
hand that has been identified as Wulfstan's own. ${ }^{20}$ In the case of the homily, the archbishop's intervention in the text is very largely confined to the continuation rather than the core of the homily, a detail which tends to correlate with the stylistic arguments in favour of Wulfstan's authorship of this continuation. ${ }^{21}$

The two remaining copies of the poem are both preserved in homily collections containing a high proportion of works associated with Wulfstan. The provenance of MS C is unknown, but it is usually dated to the early- to mid-eleventh century. ${ }^{22} \mathrm{MS} \mathrm{E}$ is later, apparently produced in the final quarter of the eleventh century, and was the first part of an extensive homiliary that appears to have been created for the use of Bishop Wulfstan II of Worcester. ${ }^{23}$ In both manuscripts, Napier I-in its distinct versions-is the first item in the homily collection. Similarities of content and structure between the two volumes suggest, moreover, that the manuscripts were related, and may have derived ultimately from a common exemplar. ${ }^{24}$ Whether this exemplar contained the longer or the shorter version of the homily is impossible to determine. It is tempting, however, to follow Wilcox in assuming the priority of the longer continuation, preserved in what is probably the earliest manuscript copy and attributed to Archbishop Wulfstan, and to see the shorter conclusion in MS E as a subsequent revision — either by Wulfstan himself or by another author — which draws heavily upon other texts associated with the archbishop. ${ }^{25}$

If our understanding of this evidence is correct, it follows that the Old English reworking of Dialogi IV. I. 1-3 that forms the core of both versions of Napier I was available in Worcester in the early years of the eleventh century. However, the origins and purpose of this part of the text before its incorporation within the two versions of Napier I remain a matter for speculation. The language of the text indicates that it is not related to the surviving Old English translation of the Dialogi, nor the later (and fragmentary) extant revision of this text. ${ }^{26}$ It is possible, of course, that this passage represents an excerpted fragment from 
another, otherwise unknown, translation of the Dialogi. So much was once suggested by Paul Szarmach, who asked whether the influence of such a lost translation might be seen not only in Napier I, but also in Vercelli homily XIV, which similarly uses Dialogi Book IV as a source. ${ }^{27}$ It will be argued below, however, that the reworking of the prison analogy in the Old English text suggests that it does not, in its present form, represent part of a wider translation of the Latin text.

It is more likely, I will suggest, that the passage from Dialogi IV. I. 1-3 was adapted for homiletic purposes even before its incorporation in the two versions of Napier homily I. Given his apparent interest in the text, it is conceivable that this adaptation might have taken place in Wulfstan's orbit. It is unlikely that the archbishop was himself responsible for the opening section of Napier I, which bears none of the hallmarks of his distinctive style and includes certain usages not otherwise found in his work. ${ }^{28}$ It is possible, however, that it may have been produced with his knowledge or even encouragement. There is some evidence to suggest that Wulfstan on occasion commissioned others to make preliminary translations of the Latin sources with which he worked. ${ }^{29}$ In such cases, however, it seems to have been Wulfstan's practice to use both the original Latin and the intermediate translation in producing his own, characteristic vernacular homilies. Moreover, David Yerkes has argued persuasively that, despite its subsequent history, the common core of the homily was not produced in Worcester. ${ }^{30}$ This part of the text may also have predated the surviving witnesses by some considerable time. The practice of dating texts from linguistic features is always contentious, but the identification of both Mercian and early West Saxon forms in the Gregorian core of Napier I has been taken as indicative of early composition and transmission. $^{31}$

It is possible that the immediate source for the Old English text of Dialogi IV. I. 1-3 preserved in Napier I was not, in fact, a full text of the Dialogi but an unidentified 
intermediary source. In a retraction of his earlier argument, Szarmach has shown convincingly that in the case of Vercelli XIV the immediate source for the Gregorian material in the vernacular homily was probably an extract from the Dialogi included in a florilegium or homiliary. ${ }^{32}$ A similar scenario might easily be imagined for the Gregorian material that forms the core of Napier I. Burchard of Worms, Wulfstan’s continental contemporary, included a longer section from Dialogi Book IV. I. 1-5, incorporating the analogy of the prison, amongst the theological texts contained in Book 20 of his Decretum, and whilst this text certainly postdates the adaptation of the Gregorian material in Napier I, it does highlight the possibility that the author of the Old English homily drew upon a lost intermediary source, rather than directly upon a copy of the Dialogi. ${ }^{33}$ Alternatively, the Anglo-Saxon author may have been drawing upon some other intermediary text which had itself drawn upon Gregory’s Latin text. ${ }^{34}$ It is not impossible, then, that the radical reworking of the ultimate source discussed below represent the intervention not of our Anglo-Saxon author, but of his immediate source.

Such uncertainty inevitably places a question mark over any attempt to analyse the Old English text's relationship with the ultimate Latin source. However, no intermediary text has yet been discovered that can account for the differences between the Old English and Gregory’s original Latin. Nor is it necessary to assume the existence of any such source. The adaptations of the Dialogi evident in Napier homily I are perfectly comprehensible as the creative and purposeful reworking of the ultimate Latin source by an Anglo-Saxon author working in the vernacular homiletic tradition and writing for a lay Anglo-Saxon audience.

\section{Style and Rhetoric in Napier Homily I}


An examination of the stylistic and rhetorical aspects of the Old English text can tell us something about the author's attitudes and purposes in relation to the ultimate Latin source. Comparison with the treatment of Dialogi IV. I. 1-3 in the Old English Dialogues is revealing. Usually identified as the translation which Asser says was produced by Wærferth, bishop of Worcester, for the personal use of King Alfred the Great, the Old English Dialogues is a precise, careful translation of the Dialogi. ${ }^{35}$ By contrast, the treatment of the Dialogi in Napier I exhibits both greater freedom from the confines of Gregory’s complex syntax and greater flair in producing a far more fluent and also more rhetorically effective vernacular text.

This can be seen by a comparison of how each text handles the complex syntax and subordination of the Latin opening to Book IV:

\section{$\underline{\text { Dialogi }}$}

Postquam de paradisi gaudiis, culpa exigente, pulsus est primus humani generis parens, in huius exilii atque caecitatis quam patimur aerumnam uenit, quia peccando extra semetipsum fusus iam illa caelestis patriae gaudia, quae prius contemplabatur, uidere non potuit. (IV. I. 1)

(After the first parent of the human race was expelled from the joys of paradise, driven by sin, he entered into the hardship of this exile and blindness which we suffer, so that, having reached beyond himself by sinning, he could no longer see those joys of the heavenly homeland, which he previously contemplated.)

\section{$\underline{\text { Old English Dialogues }}$}

Æfter pam pe Adam se æresta mæg manna cynnes wæs adrifen of neorcxnawanges gefean bædendre $\square$ nipendre his agenre scylde $\square$ becom in pa yrmðe pises wræces $\square$ blindness, 
pe we nu prowiað, forpon pe he wæs syngiende, $\square$ for pære synne he wæs onwended of his sylfes gemyndum, $\square$ he ne mihte ofer pæt geseon pa gefean pæs heofonlican eðles, pe he ær sceawode. (260:7-12)

(After Adam the first ancestor of the human race was driven from the bliss of paradise through the instigation and affliction of his own guilt and entered into the misery of this exile and blindness, which we now suffer, because he was sinning, and on account of that sin he was turned from his own state of mind, and he could not after that see the joys of the heavenly homeland, which he previously contemplated.)

\section{$\underline{\text { Napier homily I }}$}

Adam se æresta man wæs gesceapen on neorxnawonge and for his sylfes synnum panan adræfed on pas wræcworuld and on eall pa earfeðu, pe we for his synnum and ure sylfra siððan drugon, and he ða syððan pa gefean pæs heofonlican eðles, pe he ær sceawode, panonforð geseon ne mihte. (1:1-6).

(Adam the first man was created in Paradise, and for his own sins was driven thence into this world of exile and into all these miseries, which we have since suffered for his sins and for our own, and after that he could not thenceforth see the bliss of the heavenly homeland, which he previously contemplated.)

The translator of the Old English Dialogues seems, here and elsewhere, to struggle to replicate closely the syntactical construction of the original Latin text. ${ }^{36}$ By contrast, the opening of Napier I renders this same passage in a far clearer and more controlled manner. In the latter text, Gregory's rather abstract suggestion that Adam was compelled from paradise 
through the agency of sin is replaced with the more straightforward suggestion that he was driven thence for his sylfes synnum. The subordinate construction relating to the over-reaching nature of sin is similarly omitted.

In addition to simplifying the syntactical constructions of the Latin and removing Gregory's more fanciful accounts of the working of sin, the Anglo-Saxon author of the opening of Napier I also adds two small and apparently insignificant details to this opening passage. Firstly, the vernacular text replaces Gregory’s opening subordinate clause with a simple statement regarding Adam's origins as a created being. Whilst this is only a minor addition to the Latin source, it does perhaps reflect a concern with providing a stronger rhetorical opening for the Old English text. Napier I does not include any of the formulaic openings so often found in Old English homilies, such as men pa leofestan ('dearest people') or Wulfstan's preferred leofan men ('beloved people’), but the adaptation of the Latin text here does have the twin effect of beginning the homily on a main rather than a subordinate clause and taking the divine act of creation, rather than the human fall, as the homily's starting point. ${ }^{37}$ Secondly, and again with an evident rhetorical purpose, the Anglo-Saxon author adds to his text the statement that humanity has suffered misery since Adam's fall for his synnum and ure sylfra. There is, I think, a significant, if subtle, change of emphasis here. The Latin text at this point focuses attention on the spiritual blindness that humanity suffers (quam patimur) as a result of the fall. In Napier I, however, attention focuses upon humanity's enduringly sinful nature in a statement with encompasses both the author of the text and its audience.

Throughout the treatment of the prison analogy especially, Napier I continues, as Szarmach has noted, to introduce small details that serve to 'particularize' the narrative situation. ${ }^{38}$ Most notably, the text recasts Gregory’s rather arbitrary account of a pregnant women thrown into prison by emphasising the guilt of the woman and ascribing the 
punishment to royal command (sum cyning hate sum forworht wif don on carcern, 2:18-19), and also specifies that her son was twentigwintre oððe gyt yldra ('twenty years old or even older,' 3:1) at the time of her revelations about the outside world. More significant developments can be seen, however, in the passage dealing with the testimony of the mother to her son: ${ }^{39}$

\section{$\underline{\text { Dialogi }}$}

cui si fortasse mater, quae hunc genuit, solem, lunam, stellas, montes et campos, uolantes aues, currentes equos nominet, ille uero qui est in carcere natus et nutritus nihil aliud quam tenebras carceris sciat, et haec quidem esse audiat, sed quia ea per experimentum non nouit, ueraciter esse diffidat (IV. I. 3)

(Suppose his mother, who gave birth to him, describes for him the sun, the moon, the stars, the mountains and the fields, the flying birds, the running horses-truly, he who is born and nurtured in the prison might know nothing more than the darkness of the prison. He may indeed hear that these things exist, but because he had not known them by experience, he is doubtful of the truth.)

\section{Old English Dialogues}

ponne he geweaxep, gelimpeð pam cnihte, pæt seo his moder, pe hine acænde in pam carcerne, næmnað sunnan $\square$ monan, steorran $\square$ muntas $\square$ feldas $\square$ fleogende fugelas $\square$ yrnende hors, $\square$ he, se pe wæs in pam carcerne geboren $\square$ eac afeded $\square$ naht opres nat ne ne cann buton pæs carcernes pystru, $\square$ ponne he gehyreð, pæt pyslice wisan mid oðrum mannum syndon, $\square$ swa peh he geortreoweð hweper hi soðe syn, forpon pe he næfre ne cupe purh gewisse afandunge. (261:13-19) 
(when he grows, it befalls the boy that his mother, who gave birth to him in the prison, names the sun and the moon, the stars and mountains and fields and flying birds and running horses, and he who was born and also raised in that prison, and neither knows nor understands anything else except the darkness of the prison, and then hears that there are such circumstances amongst other men, and nevertheless he doubts whether they are true, because he had never known them through certain experience.)

\section{$\underline{\text { Napier homily I }}$}

Hwæt, he ponne naht oðres ne wat, butan pæt he pærinne geseah. Đeah ðe his modor him secge pæt heo gesawe sunnan and monan, steorran and streamas, muntas and feldas, fleotende fixa and fleogende fugelas and yrnende hors, wyrmas and wildeor, and eal pæt we geseoð, ic wat pæt hine wile tweogan hwæðer heo him soð secge. (3:2-7)

(Lo, then he knows nothing else except that which he sees therein. Although his mother should tell him that she saw the sun and the moon, the stars and the streams, the mountains and the fields, swimming fish and flying birds and running horses, serpents and wild animals, and all that which we see, I know that he will doubt whether she tells him the truth.)

In rendering this passage, Old English Dialogues once again displays some uncertainty in its handling of subordination and coordination in the complex sentence which is not apparent in the equivalent passage from Napier I. Beyond the reorganization and simplification of Gregory’s Latin clauses, however, Napier I’s concern with rhetorical and performative impact is suggested here by the use of interjection (hwœt), the shift into the present tense (secge, wile), and the use of both the first person singular (ic wat pret) and the first person 
plural (pæet we geseoð). In Gregory’s Latin text, the list of natural phenomenon described by the youth's mother refers initially to the sun, the moon, the stars, the mountains and the fields (solem, lunam, stellas, montes et campos). The Old English text from Napier I, however, also includes at this point a reference to 'streams' (streamas). The effect of this apparently very minor difference is to create in the Old English a chain of three two-stress phrases, linked by aural effects and emphasized syntactically by repeated conjunctions: sunnan and monan, steorran and streamas, muntas and feldas. The first and the third of these two-stress phrases feature grammatical rhyme, while the second phrase is linked by the strong st- alliteration. Grammatical rhyme also links the second phrase to both the first and third, creating a strong aural connection across the three phrases as a whole. In the same way, where the Latin goes on to mention flying birds and running horses (uolantes aues, currentes equos), the Old English has another series of three two-stress phrases, created by the addition of a reference to 'swimming fish': fleotende fixas and fleogende fuglas and yrnende hors. One effect of this addition is to complete a rhetorical triad of earth, sea and sky. Beyond this, however, the grammatical rhyme caused by both the present participle endings and the plural inflexions links the three phrases together, while the first two phrases are strongly linked by alliteration.

That the references to streams and fish may have been features of an intermediary Latin source with which the Anglo-Saxon author was working cannot be definitively ruled out. However, the effects of rhythm, alliteration, and rhyme evident here in the Old English text must be attributed to the vernacular author. Moreover, the final addition evident in this passage seems to strike a more specifically Germanic note which might have resonated especially with an Anglo-Saxon audience. The Old English text includes at this point a reference to wyrmas and wildeor for which there is no precedent in the text of the Dialogi. Not only does this phrase represent yet another alliterating two-stress phrase, but it also seems to have had some hitherto unrecognized formulaic currency in vernacular Anglo-Saxon texts. 
The phrase mirrors precisely a half-line found in the Beowulf. ${ }^{40}$ It also appears in identical or near-identical form in a range of prose texts, including The Letter of Alexander to Aristotle, ${ }^{41}$ The Old English Martyrology, ${ }^{42}$ and Napier homily XLII (197:10-11).

Taken in comparison to the equivalent section of the Dialogi, this passage from Napier I—and others like it—may be thought to demonstrate what Samantha Zacher has called the 'free 'prosaic license' that some Anglo-Saxon homilists exhibit in their treatment of Latin source material, marked in particular by 'skilled use of rhythms, stylistic flourishes, and complex rhetorical patternings', as well as 'artful use of formulas'. ${ }^{43}$ As Zacher points out, where such stylistic flourishes cannot be readily accounted for with reference to known Latin sources, they must be seen as examples of deliberate and artistic expression on the part of vernacular writers. The further stylistic features noted in the above examples from Napier

I-the concern with simplifying more complex aspects of the syntax and thought of Gregory’s Dialogi, a willingness to adopt a consciously rhetorical manner of address, and an increased sense of moral urgency, evident in the recognition of humanity's continuing failings - should also be seen as part of the Anglo-Saxon author's deliberate revision of the ultimate Latin source for a specifically Anglo-Saxon preaching context. So too should the more substantive differences that are evident in the treatment of the prison analogy in Napier I in comparison to the Dialogi.

\section{Reworking the Prison Analogy in Napier Homily I}

Immediately before embarking upon his analogy of the prison, Gregory draws a contrast between the situation of Adam, who, even after his expulsion from Paradise, is able to believe in the spiritual mysteries through his own prior experience, and that of those born into the world, who doubt because they have no personal experience upon which to draw: 
Quae nimirum dubietas primo parenti nostro esse non potuit, quia et exclusus a paradisi gaudiis, hoc quod amiserat, quoniam uiderat, recolebat. Hi autem sentire uel recolere audita non possunt, quia eorum nullum, sicut ille, saltem de praeterito experimentum tenent. (IV. I. 2)

(Which doubt, of course, could not exist for our first parent, because, though excluded from the joys of paradise, he recalled that which he had lost, since he had seen it. But they cannot, having heard, perceive with the senses or recollect, because, unlike him, none of them have experience, at least from before.)

Napier I renders the first part of this passage quite closely, but goes on to elaborate on Gregory’s general statement about carnal humanity’s lack of direct experience by suggesting that with the passing of the generations, Adam's first-hand testimony becomes increasingly less meaningful for his descendants:

Ac Adam se æresta man ne porfte he na tweogan, peah ðe he ut adrifen wære of neorxnawonges gefean, and ðeah he hit ne gesawe, pa he gemunde swaðeah pæt ylce pæt he ær geseah and pæt he ær anforlet. Ac ða syððan, pa pe he gestrynde, pa hit ne gemundan, ac peh hy gelyfdan be his segene, pe hit ær geseah, untweogendlicor ponne pa heora segene eft gelyfdon, pe æfter heom acende wæron. And syððan æghwylc fæder peh sæde his suna, and ðone æftran aa tweode ma ponne pæne ærran, forðon heora nænig pæron wæs ægper ge mid saule ge mid lichoman, swa swa Adam wæs. (2:7-17) 
(But Adam, the first man, had no need to doubt at all, although he was driven out of the joy of Paradise, and although he did not see it, when he nevertheless remembered that same, which he previously saw, and which he formerly forsook. But afterwards those who he begot did not then remember it, but nevertheless they believed according to the account of him who previously saw it, less doubtfully than those who were born after them subsequently believed their [own] account. And afterwards each father yet told his son, and the latter always doubted more than the former, because none of them was there either in soul or in body, as was Adam.)

By introducing a temporal factor at this point, the text presents the epistemological fall as progressive and incremental, in contrast to the absolute distinction that Gregory presents between Adam and the remainder of humanity taken at large. This is then reflected in the presentation of the prison analogy, which is similarly extended forward in time through the addition of a reference to the possibility of further prison-born offspring:

And gyf se cniht operne pærinne gestryneð and ðæm segeð pæt he sylf ne gesawe, ac his modor him sæde pæt heo hit eall sylf gesawe, he ponne gyt swyðor tweod ponne se ærra. $(3: 8-11)$

(And if the youth begets another therein and tells him that which he himself never saw, but which his mother told him that she herself saw completely, he will then doubt yet more than the former.)

One immediate effect of these adaptations may again be an increased sense of the moral urgency for a contemporary Anglo-Saxon audience. Indeed, this emphasis on the temporal 
dimension of the fall calls to mind the insistence in homilies associated with Wulfstan that hit is on worulde a swa leng swa wyrse ('it is in the world ever so much the longer so much the worse'). ${ }^{44}$ At the same time, however, the sense of ongoing and increasing doubt that is apparent in these passages also underpins a more radical refocusing of the prison analogy which can be seen through a comparison of the conclusion of this analogy in the Dialogi and in Napier I respectively.

As we have seen above, the progression of Gregory’s prison analogy, and of his epistemological discussion in Book IV more generally, turns upon the coming of Christ and the testimony of those subsequently granted the gift of the Holy Spirit. In Napier I, however, this pivotal point in the analogy is entirely absent. No reference is made to either Christ's coming, or the spiritual experience afforded by the Holy Spirit, and the prison analogy is brought to a very different conclusion:

Hu ne mæg se cyning ponne pæne tweon eaðe gebetan? Onlucan pæs carcernes duru: ponne magan hy pæt eall geseon, pæt him ær gesæd wæs. Đæt is ponne pæm gelicost pe we nu on carcerne syn betynede on pisse worulde, and eft ponne se gast wyrð ut of ðam lichoman alæd, pe he nu mid befangen is, ponne bið us gesawen, pæt us ær gesæd wæs, peah pe we hit nu geortrywan, forðy be we hit geseon ne magon. (3:11-18)

(Could not the king then easily remedy that doubt? Unlock the prison's door: then they could see all that which was previously told to them. That is then most like that we are now enclosed in prison in this world, and when the spirit is afterwards led out of the body with which it is now enveloped, then will be visible to us that which was previously told to us, although we now doubt it because we cannot see it.) 
There are, again, elements here—-such as the rhetorical question, the first person plural pronouns, and the careful use of tenses and temporal adverbs to establish a contrast between present doubt, prior testimony, and future certainty $(n u . . . e f t$

ponne...nи...ponne...ær...nи...)—that demonstrate the sort of artistic and rhetorical crafting discussed by Zacher. More significantly, however, the adaptation of the analogy drastically undermines Gregory’s original message. In keeping with the emphasis on ever increasing uncertainty and continuity of sin in the earlier parts of the homily, the conclusion to the prison analogy in Napier I denies the possibility of true knowledge of the spiritual mysteries within the world. While the Dialogi attempt to show why the fate of believers within the world need not be like that of the youth born in prison, the analogy in Napier I instead insists, almost casually, upon the absolute epistemological limits of human experience. Through the suggestion that certainty concerning spiritual matters is possible only after death, the text implicitly privileges a kind of blind faith antithetical to Gregory’s intellectual and rational approach.

These differences argue strongly against the possibility that the core of Napier I represents an excerpt from a lost translation of the Dialogi. As it stands in the vernacular text, it is hard to see how the analogy of the prison could support Gregory’s wider teaching in Book IV concerning the essentially rational nature of the Christian faith. This being the case, it is possible that the changes in Napier I reflect the author's ignorance of the part that the analogy plays in Book IV, either because this author was working with an intermediate source that transmitted only a part of chapter I, or because of a failure to fully comprehend Gregory’s epistemological arguments.

Yet we can also explain the differences between the two texts in terms of conscious homiletic reshaping on the part of the Anglo-Saxon author. The epistemological arguments in Dialogi Book IV constituted Gregory’s direct, intellectual response to specific, empiricist 
challenges to Church teaching mounted in Rome in the last decade of the sixth century. In this respect, the Dialogi are, very much, a product of their time. Presenting a defence against such rationalist arguments may, however, have been a less pressing concern for the author of the vernacular Anglo-Saxon text. The rhetorical and stylistic presentation of the core of this text, as well as, more obviously, its subsequent reuse in the two surviving versions of Napier I, place the text in a vernacular homiletic context. In such a context—and possibly with an uneducated lay audience in view—reasoned intellectual argument may have been less important to the Anglo-Saxon author than an appeal to faith.

By moving the focus from the possibility of belief within the prison to the image of release from the prison, the Anglo-Saxon author removes the potentially confusing shift that takes place in Gregory’s analogy concerning the testimony of the mother. The changes also align the analogy in a more straightforward manner with the rich Christian tradition—wellrepresented in Anglo-Saxon literature-of metaphorical representations of death as a release from the worldly (or bodily) prison. ${ }^{45}$ The rhetorical power of such metaphors may indeed have exerted an influence on the reworking of the Gregorian analogy. With its embedded theme of contempt for the world and the promise of freedom to come, the analogy in Napier I, in comparison to the Latin text, is less a rational argument than it is an exhortation to belief.

A useful parallel for this reworking of Dialogi IV. I. 1-3 might be found in the anonymous Old English homiletic adaptation of Adso of Montier-en-Der's Libellus de Antichristo in Napier homily XLII. In an examination of the relationship between the Latin and vernacular texts, Richard Emmerson has noted how the Anglo-Saxon author both makes specific changes that suggest an awareness of 'the cultural distinctions between [an AngloSaxon] audience and the more learned audience of the Latin original', and also adopts an exhortatory tone that, whilst it 'lacks the scholarly detachment of the Libellus', is 'much more rhetorically persuasive'. ${ }^{46}$ The approach that Emmerson describes is very much what we see 
in Napier I's reworking of the Dialogi. Like Napier XLII, then, Napier I should be viewed not 'as a mere translation' but as 'an original work well suited to the homilist's purposes'. ${ }^{47}$

\section{Continuations and Conclusions}

The radical nature of the reworking of the prison analogy in the core of Napier I can be seen in the relation of this common core to each of the two different continuations subsequently appended to it. In each copy of the homily, the text continues after the conclusion of the prison analogy with the following passage:

Ac ealles to lytel andgyt bið peah on ðæs mannes heortan, pe nele soðes gelyfan, peh he sylf his agenum eagum eal ne gesawe, pæt soðes is geworden. La, hwæt byð betweonan mannes and nytenes andgyte, gyf he nat ne witan nele butan pæt he on starað? Ac se byð wita, se ðe soð asmeað, and se ðe fela wat pæs pe ær wæs and æfter gewurðan sceal. (3:19-4:4)

(But there is nevertheless all too little reason in the heart of the man who will not truly believe that which is truly come to pass, even if he may not see it all with his own eyes. Lo, what is the difference between a man's reason and that of a beast, if he knows not and does not wish to know anything except that on which he gazes? But he is a wise man who enquires about the truth, and who knows many of those things which previously were and which must afterwards occur.)

The textual history and status of these lines is complex. For Karl Jost, they are part of the common core of the homily. ${ }^{48}$ However, Angus McIntosh, Bethurum, and Wilcox all identify this passage as the work of Wulfstan, marking the beginning of his continuation of the longer 
text of the homily. ${ }^{49}$ The latter view is supported by the fact that the word ealles in this passage is an interlinear addition in Wulfstan's hand in the text contained in MS L. More tellingly, the passage also resembles very closely a feature of Wulfstan's homiletic style identified by Bethurum, whereby the archbishop pauses at a key moment of the homily 'to reflect upon some ethical or religious truth that has struck him'. ${ }^{50}$ According to Bethurum, this pause, which 'usually takes the form of a rhetorical question or an exclamation', often marks the start of 'the next division of the sermon' ${ }^{51}$

The question of the authorship of these lines is significant in so far as it impacts upon our understanding of the relationship of the two versions of Napier I. The recognition that these lines comprise the beginning of Wulfstan's continuation in the longer text, rather than part of the common core of the homily, strongly supports the suggestion that the shorter version of the text represents a direct adaptation of the longer. The presence of these lines also emphasizes the composite nature of Napier I, as the use of a rhetorical strategy associated with the marking-off of sections of a homily occurs in both versions of the text at the join between the core of the homily and the subsequent continuation. This observation might further suggest that the shorter redaction of the homily was produced either by the archbishop himself or by somebody familiar with his compositional techniques.

However, perhaps the most striking thing about these lines is how badly they seem to fit with the preceding prison analogy. In a general sense, the exhortation to faith in that which cannot be seen with the eyes of the body accords well with Gregory's argument in Dialogi Book IV, as does the appeal to human reason (andgyte) as a grounds for belief. Yet no rational basis for this belief has been provided by the foregoing text of Napier I, and in the absence of the Dialogi's pivotal reference to the coming of Christ and the grace of the Holy Spirit, the reproach implicit in this passage seems out of step with what has gone before. 
The shorter text of the homily continues from this point with a generic conclusion that seems to connect to the preceding text only in so far as it furnishes it with an explicitly homiletic and hortatory ending. However, the longer text of the homily continues with a discussion of the miracles of the saints and the joys of heaven that constitutes a very loose, but definitely recognizable translation of some sentences from Book IV chapter VI of the Dialogi:

And sylfe we gesawon pæs swutele bysene: we gesawan for oft æt sumra pæra byrgenan, pe gode wel gecwemdan, manege gefettan lichamlice hæle [...] Be pam man mæg gecnawan and be ma pinga, pæt pær synda mihta, mærpa and myrhpa, pær ða motan wunjan æfter heora liffæce, pe godes willan wyrcað and wisdomes gymað pa hwile be hy libbað. (4:9-5:7)

(And we ourselves have seen this clear example: very often we have seen many receive bodily health at the graves of some of those who fittingly pleased God [...] By that, and by other things, one can know that there is power, glory and joy there where those who obey God's will and give heed to wisdom while they live can dwell after their lifetime.)

The continued use of the Dialogi as a source in this continuation may once more reflect the popularity of the text in this period. However, the passage itself, with its apparent confidence in the evidential basis for belief in the rewards of heaven, again sits oddly alongside the adapted analogy of the prison in Napier I. The continuation seems here to be following the logic of the Latin Dialogi with little regard to the reworking of the text in the earlier part of the homily.

The logical discrepancy apparent between the core text of Napier I and the longer continuation is emphasized by the stylistic discontinuity between the two parts of the homily. 
Given that the longer continuation appears to have been composed by Wulfstan specifically to supply a homiletic conclusion for the adaptation of Dialogi IV. I. 1-3, it is surprising that the archbishop did not, as seems to have been his custom elsewhere, rework the pre-existing text for his own purposes and in his own idiosyncratic style. ${ }^{52}$ However, Wulfstan's treatment of the Latin text in his continuation does provide a useful point of comparison for the adaptation of the prison analogy in the earlier part of the homily. In the equivalent section of the Dialogi, Gregory is once more extending what he presents as a rational basis for belief. ${ }^{53}$ Starting from the proposition that the existence of the invisible soul within the living body is discernible only through outward, physical actions, Gregory asserts that the miracles associated with saintly relics similarly provide visible evidence for the life of the soul after death. Belief in the postmortem survival of the soul, he suggests, is therefore no more or less rational and experiential than belief in its existence in the living body:

Pensa itaque eorum animae qualiter uiuunt illic, ubi uiuunt, quorum hic et mortua corpora in tot miraculis uiuunt. Si igitur uitam animae manentis in corpore deprehendis ex motu membrorum, cur non perpendis uitam animae post corpus etiam per ossa mortua in uirtute miraculorum? (IV. VI. 2)

(Consider, then, in what manner their souls are living there where they now live, if here even their dead bodies are alive in so many miracles. If, then, you perceive the enduring life of the soul in the body from the movement of the limbs, why will you not similarly recognize the life of the soul after the body by virtue of the miracles performed by the dead bones?)

Such precise, logical argument is not replicated, however, in the text of Napier I, in which Wulfstan focuses the attention of the text more narrowly on the rewards for virtue that are to 
be had in heaven—a topic that might have had more value and didactic force in a vernacular preaching text than the more sophisticated epistemological enquiries of the Dialogi.

That Archbishop Wulfstan should be found to rework an authoritative Latin source text, both stylistically and more substantively, need not be surprising. The freedom with which Wulfstan adapts his source material has been long acknowledged, and 'dramatic recasting' of pre-existing texts has been seen as characteristic of his homiletic practice. ${ }^{54}$ What is perhaps more significant, however, is that a similarly dramatic reworking of this same Latin source is also evident in the work of the anonymous author of the common core of Napier homily I.

The treatment of Gregory’s Dialogi throughout the longer version of Napier I, by two different Anglo-Saxon authors, thus displays a markedly different approach to the Latin source than is evidence in the very close translation of the text in the Old English Dialogues. The differences relate, of course, to the specific and divergent interests of the different vernacular authors. The careful rendition of the Latin text in the Old English Dialogues has been taken to reflect both the esteem in which the Latin original was held, and also the likely purpose of the translation as a guide to the original text. ${ }^{55}$ Throughout the course of the text, the translator is concerned to minimize the differences between the Latin and the Old English as far as possible, and the treatment speaks of a respect for, if not reverence towards, Gregory’s work. By contrast, the treatment of the text in Napier I reveals an attitude towards the Dialogi which is at once pragmatic and creative: pragmatic in its use of the Dialogi as a resource for preaching materials; creative in its extensive and unconstrained reworking of this material to suit the needs of an Anglo-Saxon audience.

The pragmatism evident in the use of the Dialogi in Napier I accords well with other evidence for the association of Book IV of Gregory’s text with vernacular preaching. David Johnson and Winfried Rudolf have recently identified as many as eighteen interventions to 
the text of the Old English Dialogues found in London, British Library, Cotton Otho C. i, which they attribute to the Worcester monk Coleman (d. 1113). All of these annotations relate to Book IV of the Old English text, and Johnson and Rudolf conclude that Coleman was identifying exemplary, but not explicitly homiletic material that could be adapted for preaching purposes. ${ }^{56}$ Coleman's activities thus reveal in practice just such an attitude towards Gregory’s text as can be inferred from the evidence of Napier I.

That Coleman is working directly with a full, albeit vernacular, text of the Dialogi also lends credence to my suggestion that we need not assume the influence of an otherwise unknown intermediary source to explain the differences between Napier I and the equivalent sections of Gregory’s text. Rather, I suggest, Napier I provides an illuminating example of the freedom and creativity with which individual Anglo-Saxon homilists could on occasion rework even the most authoritative of Latin sources. If we are willing to engage with the Old English text as a response to, rather than a misrepresentation of, Gregory’s text, it also enables us tentatively to reconstruct something of the interests and needs of Anglo-Saxon vernacular preachers. Arguing against an overly-cautious scholarly tendency to downplay the accomplishments of vernacular prose writers, Samantha Zacher has urged that 'it is time to treat Old English prose, even anonymous and unsourced Old English prose, not as the poor relation of Latin, but rather as a remarkable and characteristically Anglo-Saxon vehicle for the artful expression of specifically Anglo-Saxon concerns'. ${ }^{57}$ The example of the rewriting of Gregory the Great’s prison analogy in Napier homily I suggests that such an approach might be richly rewarding. 
${ }^{1}$ Michael Lapidge, The Anglo-Saxon Library (Oxford, 2006), 304; 39 n.48, 80, 82-3, 87-8.

${ }^{2}$ Ibid., 127.

${ }^{3}$ Bischof Wcerferth von Worcester Übersetzung der Dialoge Gregors des Grossen, ed. Hans Hecht (Leipzig, 1900-7), vol. 1. On the influence of the Dialogi in Anglo-Saxon authors, see Mechthild Gretsch, Elfric and the Cult of Saints in Late Anglo-Saxon England (Cambridge, 2005), 136-41; Lapidge, Anglo-Saxon Library, 304.

${ }^{4}$ Wulfstan: Sammlung der ihm zugeschriebenen Homilien, ed. Arthur Napier (Berlin, 1883), 1-5, with minor changes to punctuation and capitalization. All translations are my own. Manuscript sigla follow this edition.

${ }^{5}$ Grégoire le Grand. Dialogues, ed. Adalbert de Vogüé, tr. Paul Antin, 3 vols, Sources Chrétiennes, 251, 260, 265 (Paris, 1978-80).

${ }^{6}$ Napier I 4:4-5:16. The longer continuation of Napier I begins at p. 9:10 in MS C and at f. 116r:9 in MS L.

${ }^{7}$ For this ending, which begins at f. $2^{\mathrm{v}}: 12$, see Napier I 4:4n.

${ }^{8}$ Angus McIntosh, 'Wulfstan’s Prose’, Proceedings of the British Academy, 35 (1949), 109-42, 42 n.32(a); Karl Jost, Wulfstanstudien (Bern, 1950), 184-7; The Homilies of Wulfstan, ed. Dorothy Bethurum (Oxford, 1957), 41-2; Jonathan Wilcox, ‘The Dissemination of Wulfstan’s Homilies: the Wulfstan Tradition in EleventhCentury Vernacular Preaching', in Carola Hicks (ed.), England in the Eleventh Century (Stamford, 1992), 199217, 204-5; Joyce Tally Lionarons, The Homiletic Writings of Archbishop Wulfstan: A Critical Study (Cambridge, 2010), 28-9. See also the more detailed discussion in section II below.

${ }^{9}$ Jost (Wulfstanstudien, 184-7) and Paul E. Szarmach ('Another Old English Translation of Gregory the Great’s Dialogues?', English Studies, 62 (1981), 97-109) are notable exceptions.

${ }^{10}$ Dorothy Whitelock (Sermo Lupi ad Anglo, $3^{\text {rd }}$ edn (London, 1963), 22), Bethurum (Homilies, 41), Donald Scragg ('The corpus of vernacular homilies and prose saints’ lives before Ælfric’, Anglo-Saxon England, 8 (1979), 223-77, 102), and Lionarons (Homiletic Writings, 28) all refer to the Gregorian core of Napier I simply as a 'translation' of the Dialogi. David Yerkes ('The Place of Composition of the Opening of Napier Homily I', Neophilologus, 60 (1976), 452-4, 452) describes it as a 'free translation'. Wilcox ('Dissemination’, 204) says that the material is 'drawn from' the Dialogi.

${ }^{11}$ Adalbert de Vogüé, 'Un avatar du mythe de la caverne dans les Dialogues de Grégoire le Grand', in Homenaje a Fray Justo Perez de Urbel, OSB (Silos, 1976-77), vol. 2, 19-24; Wilhelm Blum, Höhlengleichnisse: Thema mit Variationen (Bielefeld, 2004), 68-73; Meinolf Schumacher, 'Noch ein 
Höhlengleichnis: Zu einem metaphorischen Argument bei Gregor dem Großen’, Literaturwissenschaftliches Jahrbuch, 31 (1990), 53-68.

${ }^{12}$ For an indication of the ubiquity of prison imagery in early Christian writing, see Klaus R. Grinda, Enzyklopädie der literarischen Vergleiche: Das Bildinventar von der römischen Antike bis zum Ende des Frühmittelalters (Paderborn, 2002), 729-31. On Gregory’s engagement with contemporary theories and practices of imprisonment, see Julia Hillner, ‘Gregory the Great’s ‘Prisons’: Monastic Confinement in Early Byzantine Italy’, Journal of Early Christian Studies, 19 (2011), 433-71.

${ }^{13}$ Matthew dal Santo, Debating the Saints' Cult in the Age of Gregory the Great (Oxford, 2012), 85-148.

${ }^{14}$ Ibid., 107.

${ }^{15}$ Ibid., 92-3.

${ }^{16}$ McIntosh, ‘Wulfstan’s Prose’, 114-5; Jost, Wulfstanstudien, 184-6; Wilcox, 'Dissemination', 204-5. Cf. Bethurum XIII 8-11. On Wulfstan's style and idiom, see the recent discussion in Sara M. Pons-Sanz, NorseDerived Vocabulary in Late Old English Texts: Wulfstan’s Works, a Case Study (Odense, 2007), $26-31$.

${ }^{17}$ Napier I 4:4n. Cf. Napier XXV 123:16-124:7; Napier XL 189:11-15; Bethurum II 65-9. The conclusion also refers to the importance of upholding one's baptismal promises in terms that occur frequently in homilies associated with Wulfstan. Cf. Bethurum VIIIc 116-20, Bethurum Xc 36-8, Bethurum XIII 22-3, Bethurum XX(BH) 121-3, Napier XXX 144:5-7.

${ }^{18}$ N. R. Ker, Catalogue of Manuscripts Containing Anglo-Saxon (Oxford, 1957), no. 190; Lionarons, Homiletic Writings, 21.

${ }^{19}$ Stephen Baxter, ‘Archbishop Wulfstan and the Administration of God's Property’, in Matthew Townend (ed.), Wulfstan, Archbishop of York: the proceedings of the second Alcuin conference (Turnhout, 2004), 161205.

${ }^{20}$ Neil Ker, ‘The Handwriting of Archbishop Wulfstan’, in Peter Clemoes and Kathleen Hughes (eds), England Before the Conquest: Studies in Primary Sources Presented to Dorothy Whitelock (Cambridge, 1971), 315-31. Though copied in a different hand to those of the cartulary_-dated 's.xi' ' by Ker (Catalogue, no. 190)—the evidence of Wulfstan's annotations suggests that the homily was added to the manuscript at an early stage.

${ }^{21}$ Wilcox, ‘Dissemination', 205.

${ }^{22}$ Ker, Catalogue, no. 49; Lionarons, Homiletic Writings, 13-4.

${ }^{23}$ Ker, Catalogue, no. 331; Lionarons, Homiletic Writings, 12-3.

${ }^{24}$ Homilies, ed. Bethurum, 2-4, 9-12. 
${ }^{25}$ Wilcox, 'Dissemination’, 205, 210. Cf. Jost, Wulfstanstudien, 186-7.

${ }^{26}$ Jost, Wulfstanstudien, 184-5. David Yerkes, 'Composition', 452-4. On the various texts of the Old English Dialogues, see David Yerkes, ‘The Translation of Gregory’s Dialogues and Its Revision: Textual History, Provenance, Authorship', in Paul E. Szarmach (ed.), Studies in Earlier Old English Prose: Sixteen Original Contributions (Albany, 1986), 335-43.

${ }^{27}$ Szarmach, ‘Another Translation’.

${ }^{28}$ Jost, Wulfstanstudien, 184. It may be noted at this point that, as Bethurum has pointed out (Homilies, 91), Wulfstan seems to have generally avoided elaborate figurae sententiarum of the kind represented by Gregory's prison analogy. Cf. Pons-Sanz, Norse-Derived Vocabulary, 27.

${ }^{29}$ Lionarons, Homiletic Writings, 141.

${ }^{30}$ Yerkes, ‘Composition’, 452-3. Wilcox ('Dissemination’, 205 n. 51) misrepresents Yerkes, whose arguments apply only to the common Gregorian core of Napier I, not (as Wilcox states) to the continuation of the homily in MSS L and C.

${ }^{31}$ The Life of St. Chad: An Old English Homily, ed. Rudolf Vleeskruyer (Amsterdam, 1953), 59. See also, Samuel R. Levin, 'On the Authenticity of Five 'Wulfstan' Homilies', Journal of English and Germanic Philology, 60 (1961), 451-9.

${ }^{32}$ Paul E. Szarmach, 'Vercelli Homily XIV and the Homiliary of Paul the Deacon’, Leeds Studies in English, 37 (2006), 75-87.

${ }^{33}$ Patrologia Latina, ed. Jacques-Paul Migne, vol. 140 (Paris, 1853), cols. 1021B-22A. On the date of the Decretum, see Greta Austin, Shaping Church Law Around the Year 1000: the Decretum of Buchard of Worms (Farnham, 2009), 20-1.

${ }^{34}$ Gregory's account of the fall in Book IV. I is a source for the Latin homily De Incarnatione Filii Dei et humani generis reparation, attributed to Boniface and recorded in a continental manuscript of the mid-ninth century (Patrologia Latina, ed. Migne, vol. 89 (Paris, 1850), cols. 862A-63C). Here, however, the analogy of the prison is specifically omitted. For the use of the analogy in later medieval German preaching material, see Meinolf Schumacher, ‘Eyn meyster und s. Gregor sprechent: Das ‘Höhlengleichnis’ Gregors des Großen bei Heinrich Seuse und in deutschen Predigten des Spätmittelalters’, Literaturwissenschaftliches Jahrbuch, 33 (1992), 362-6. 
${ }^{35}$ Asser's Life of King Alfred, ed. W. H. Stevenson (Oxford, 1904), 62-3. On the translator's method throughout the Dialogues, see Christine Thijs, 'Wærferth's Treatment of the Miraculous in his Old English Translation of Gregory’s Dialogi', Notes \& Queries, 53 (2006), 272-86, 273-4.

${ }^{36}$ See further M. R. Godden, 'Wærferth and King Alfred: the Fate of the Old English Dialogues', in Jane Roberts and Janet L. Nelson with Malcolm Godden (eds), Alfred the Wise: Studies in honour of Janet Bately on the occasion of her sixty-fifth birthday (Cambridge, 1997), 35-51, 44-7.

${ }^{37}$ This opening may explain the rubric De initio creature that accompanies the text of Napier I in MS E. On Wulfstan’s preferences for leofan men as a homiletic opening, see Lionarons, Homiletic Writings, 11.

${ }^{38}$ Szarmach, ‘Another Translation', 107-8.

${ }^{39}$ Ibid., 108.

${ }^{40}$ Klaeber's Beowulf: Fourth Edition, ed. R. D. Fulk, Robert E. Bjork, and John D. Niles (Toronto, 2008), 1430a.

${ }^{41}$ Andy Orchard, Pride and Prodigies: Studies in the Monsters of the Beowulf-Manuscript (Cambridge, 1985), 242, 246, 248.

${ }^{42}$ The Old English Martyrology: Edition, Translation, and Commentary, ed. Christine Rauer (Cambridge, 2013), 100.

${ }^{43}$ Samantha Zacher, 'Reading the Style and Rhetoric of the Vercelli Homilies', in A. J. Kleist (ed.), The Old English Homily: Precedent, Practice and Appropriation (Turnhout, 2007), 173-207, 206, 173.

${ }^{44}$ Cf. Bethurum Ib 22-4; Bethurum III 14-15; Bethurum V 44-7; Bethurum XX (B, H) 3-6; (C) 7-9; (EI) 7-11; Napier XL 189:5-9; Napier L 273:1-4.

${ }^{45}$ See especially, Chad, ed. Vleeskruyer, 174:144-8; Blickling II, The Blickling Homilies of the Tenth Century, ed. R. Morris, EETS os 58, 63, 73 (London, 1880), 19:23-5; The Old English Boethius: An Edition of the Old English Versions of Boethius's De Consolatione Philosophiae, ed. Malcolm Godden and Susan Irvine with Mark Griffith and Rohini Jayatilaka, 2 vols (Oxford, 2009), B.18:129-32/CP.9:154-8; King Alfred's Version of St Augustine’s Soliloquies, ed. Thomas A. Carnicelli (Harvard, 1969), 86:24-87:2; 93:14-16. See also Helen Foxhall Forbes, Heaven and Earth in Anglo-Saxon England: Theology and Society in an Age of Faith (Farnham, 2013), 75 and note 12 above.

${ }^{46}$ Richard Kenneth Emmerson, 'From Epistola to Sermo: The Old English Version of Adso's Libellus de Antichristo', Journal of English and Germanic Philology, 82 (1983), 1-10, 5.

${ }^{47}$ Ibid., 10. 
${ }^{48}$ Jost, Wulfstanstudien, 184-6.

${ }^{49}$ McIntosh, 'Wulfstan’s Prose’, 42 n.32(a); Homilies, ed. Bethurum, 41-2; Wilcox, 'Dissemination’, 205.

${ }^{50}$ Homilies, ed. Bethurum, 95.

${ }^{51}$ Ibid. Of the examples cited by Bethurum, those at Bethurum IV 83-6, Bethurum VI 154-8, Bethurum XIII 42-5, and Bethurum XX (EI) 127-8 are closest to the passage from Napier I.

${ }^{52}$ Compare Andy Orchard's characterization of Wulfstan as a writer who 'happily recasts, embellishes, and generally appropriates the material he uses' ('Wulfstan as reader, writer and re-writer', in A. J. Kleist (ed.), The Old English Homily: Precedent, Practice and Appropriation (Turnhout, 2007), 319-20, 335). Jost

('Wulfstanstudien', 187) could find no answer to the question of why Wulfstan had not revised the earlier part of Napier I ('Auf diese Frage weiss ich keine Antwort'). Lionarons, by contrast, argues that the evidence of Napier I suggests that scholars have been too quick to dismiss as the work of imitators or interpolators homilies in which material attributed to Wulfstan is combined with unrevised work by other hands (Homiletics Writings, 29).

${ }^{53}$ Dal Santo, Debating the Saints’ Cult, 98-100.

${ }^{54}$ Orchard, ‘Reader, writer and re-writer', 316. On Wulfstan’s use of sources, see recent discussions by Andy Orchard ('The library of Wulfstan of York', in Richard Gameson (ed.), The Cambridge History of the Book in Britain, Volume I, c. 400-1100 (Cambridge, 2012), 694-700) and Andrew Rabin (ed. and trans., The Political Writings of Archbishop Wulfstan of York (Manchester, 2015), 25-31).

${ }^{55}$ Thijs, ‘Wærferth’s Treatment’, 276.

${ }^{56}$ David F. Johnson and Winfried Rudolf, 'More Notes by Coleman’, Medium Ævvum, 79 (2010), 113-25, 122.

${ }^{57}$ Zacher, 'Style and Rhetoric’, 207. 